\title{
PENGARUH SOCIAL MEDIA MARKETING TERHADAP CUSTOMER ENGAGEMENT DENGAN LOYALITAS MEREK DAN KEPERCAYAAN SEBAGAI VARIABEL MEDIASI
}

\author{
Rachmadhaniyati \\ Universitas Negeri Surabaya \\ rachmadhaniyati.17080574026@mhs.unesa.ac.id \\ Sanaji \\ Universitas Negeri Surabaya \\ $\underline{\text { sanaji@unesa.ac.id }}$
}

\begin{abstract}
The rapid development of technology has an impact that can be seen from changes in people's lifestyles. Some marketers take advantage of this technological development by marketing their products through social media. For this reason, marketers must also be able to adjust marketing channels through social media so that users can access them easily. Marketing tools through social media are the marketplace, Facebook, Twitter, Instagram, and others. This study aims to determine the effect of social media marketing on customer engagement with brand loyalty and trust as mediating variables on online shop actors. This study uses 200 samples collected through an online questionnaire with a purposive sampling technique with criteria of at least 16 years of age, active social media users, and having shopped online. We used the Partial Least Square (PLS) method to test the hypothesis. The results of this study indicate that social media marketing affects customer engagement. This study also proves that brand loyalty and trust have a significant relationship with social media marketing. However, it was found that trust did not affect customer engagement. That is, trust is not able to strengthen the influence of social media marketing on customer engagement.
\end{abstract}

Keywords: brand loyalty; customer engagement; online shop; social media marketing; trust.

\section{PENDAHULUAN}

Saat ini kemajuan teknologi sangat cepat. Kemajuan teknologi tidak bisa dihindari dalam kehidupan ini, karena akan berjalan sesuai dengan kemajuan ilmu pengetahuan. Teknologi juga memberikan banyak kemudahan serta sebagai cara baru dalam melakukan aktivitas manusia (Ngafifi, 2014). Kemajuan teknologi memungkinkan manusia untuk terhubung satu sama lain tanpa dibatasi jarak, ruang, dan waktu (Daeng et al., 2017). Selain berfungsi sebagai media komunikasi, social media juga digunakan untuk sarana berjualan, berbagi informasi terbaru, ataupun membentuk opini tentang sebuah produk (Imron et al., 2018). Online shop merupakan tempat di mana jual-beli dilakukan melalui internet yang memungkinkan konsumen untuk dapat membeli secara langsung dari penjual. Toko online atau online shop bisa dikatakan sebagai tempat berjualan yang sebagian besar aktivitasnya berlangsung secara online di internet (Juju \& Studio, 2013).

Perkembangan teknologi informasi yang begitu pesat termasuk internet membawa dampak yang besar bagi segala aspek, tidak terkecuali perkembangan dunia bisnis dan pemasaran. Hal ini tidak aneh mengingat jumlah pengguna internet yang terus tumbuh pesat dapat menjadi sebuah pasar yang potensial untuk dimasuki para pebisnis karena mempunyai banyak keuntungan baik bagi perusahaan atau pun konsumen (Mujiyana \& Elissa, 2013). Tren marketplace terus berkembang seiring berkembangnya teknologi dengan pertumbuhan rata-rata setiap tahunnya mencapai 17\%. Data perkembangangan marketplace per Q1 2021 pada pengunjung sebagai berikut: Tokopedia sebanyak 135.076 juta pengunjung, Shopee sebanyak 127.400 juta pengunjung, Bukalapak sebanyak 34.170 juta pengunjung, Lazada sebanyak 30.516 juta pengunjung, dan Blibli sebanyak 19.590 juta pengunjung (Wasli, 2021). Data ini menunjukkan besarnya minat konsumen terhadap online shop di mana internet tidak hanya menjadi media hiburan semata namun juga bisa digunakan untuk berbisnis dan berbelanja. 
Riyanto (2020) menyatakan total jumlah penduduk 271,2 juta jiwa, dengan pengguna mobile unik 338,2 juta jiwa, pengguna internet 175,4 juta jiwa dan pengguna media sosial aktif 160 juta. Kehidupan berbasis internet sangat penting dan hampir 90\% kaum muda memanfaatkan kehidupan berbasis web. Dengan begitu para pemasar yang memanfaatkan internet dan media sosial dapat dengan mudah menyampaikan informasi kepada jutaan calon konsumen dalam waktu singkat. Dissanayake et al. (2019) menyatakan media sosial memberikan pilihan tambahan bagi pemasar untuk melacak perhatian konsumen guna membangun kesadaran merek dan keterlibatan konsumen. Sejumlah perusahaan juga menggunakan social media sebagai wadah untuk menampung pendapat, kritikan, dan masukan konsumen. Dalam menjaga hubungan perusahaan dengan pelanggan merupakan hal penting yang harus dilakukan oleh setiap perusahaan.(Imron et al., 2018). Oleh karena itu, social media marketing juga membutuhkan customer engagement yaitu proses psikologis yang membentuk model mekanisme sebagai dasar loyalitas pelanggan suatu merek baru, di mana loyalitas pelanggan dapat dipertahankan untuk pembelian berulang suatu merek (Bowden, 2009).

Beberapa penelitian terdahulu menyampaikan hasil yang berbeda-beda mengenai pengaruh social media marketing terhadap customer engagement (Dissanayake et al., 2019; Rudyanto, 2018; Farook \& Abeysekera, 2016). Dissanayake et al. (2019) menyatakan customer engagement dan evaluasi merek dapat menghasilkan perilaku loyalitas yang memberikan manfaat jangka panjang bagi suatu merek. Rudyanto (2018) menyatakan media sosial berhubungan signifikan dengan niat beli, di mana customer engagement sebagai variabel mediasi. Di sisi lain, terdapat korelasi lemah antara social media marketing dengan customer engagement (Farook \& Abeysekera, 2016). Selain itu, Laksamana, 2018; Hannief \& Martini, 2018) menyatakan terdapat pengaruh antara social media marketing terhadap loyalitas merek. Zulfikar (2017) menyatakan terdapat pengaruh antara social media marketing terhadap trust. Sukamdewi \& Prihatsanti (2018) menyatakan terdapat hubungan positif signifikan antara trust dengan customer engagement. Semakin tinggi brand trust maka semakin tinggi customer engagement. Purnami (2017) menyatakan loyalitas merek berpengaruh signifikan terhadap customer engagement, dengan begitu semakin tinggi persepsi nilai dari konsumen terhadap produk yang ditawarkan di media sosial maka semakin tinggi pula keinginan konsumen untuk terlibat dalam aktivitas customer engagement yang dilakukan perusahaan. Berbeda dengan Rahmawati \& Sanaji, (2015) menyatakan customer engagement tidak berpengaruh terhadap loyalitas merek. Berdasarkan paparan di atas maka digunakan variabel mediasi karena loyalitas merek dan trust merupakan mediator yang baik. Konsumen akan lebih loyal ketika dibuat percaya terlebih dahulu terhadap suatu merek (Kristianto \& Juanedi, 2013).

Social media marketing dapat meningkatkan tingkat engagement, dan loyalitas merek karena melalui media sosial perusahaan dapat menciptakan alur komunikasi dua arah yang langsung, komunikasi yang interaktif dan menarik serta cepat dengan para pelanggan (Hidayah, 2019). Para pelanggan yang loyal cenderung berbelanja lebih sering dan mencoba produk-produk yang lain dari perusahaan itu serta memberi tahu kepada orang lain tentang pengalaman baik yang mereka peroleh saat menggunakan produk atau jasa tersebut dan membawa para pelanggan baru ke dalam perusahaan (Kotler \& Armstrong, 2011). Yang menjadi faktor pembentuk loyalitas pelanggan adalah kepercayaan pelanggan terhadap merek. Kepercayaan didefinisikan sebagai kesediaan untuk bergantung pada pihak lain yang dipercaya (Ishak \& Luthfi, 2011). Dalam hal ini kepercayaan menjadi dasar bagi perusahaan untuk melakukan transkasi bisnis dengan perusahaan lain. Kepercayaan terjalin antara konsumen baik dengan karyawan, perusahaan, dan merek perusahaan dapat menjadikan hubungan erat untuk mengembangkan produk baru dan menawarkannya kepada konsumen (Veno \& Subagio, 2013). Berdasarkan paparan di atas, penelitian ini bertujuan untuk mengetahui pengaruh pemasaran media sosial terhadap keterlibatan pelanggan dengan loyalitas merek dan kepercayaan sebagai variabel mediasi pada pelaku online shop.

\section{KAJIAN PUSTAKA DAN PENGEMBANGAN HIPOTESIS}

\section{Social Media Marketing}

Media sosial dijadikan sebagai strategi yang efektif karena dapat meningkatkan keterlibatan pelanggan yang berdampak pada loyalitas merek (Vivek et al., 2012). Menurut Weinberg (2009), 
pemasaran media sosial atau social media marketing adalah sebuah proses yang mendorong individu untuk melakukan promosi melalui situs web, produk, atau layanan mereka melalui saluran sosial online dan untuk berkomunikasi dengan memanfaatkan komunitas yang jauh lebih besar yang memiliki kemungkinan lebih besar juga untuk melakukan pemasaran daripada melalui saluran periklanan tradisional.

Social media marketing adalah pemanfaatan teknologi, saluran dan perangkat media sosial untuk membuat berkomunikasi, menyampaikan dan bertukar penawaran yang memiliki nilai bagi pemangku kepentingan organisasi (Tuten et al., 2015). Media sosial memainkan peran ketika kegiatan pemasaran perusahaan membangun hubungan individu dengan pelanggan dan memberi perusahaan peluang untuk mengakses pelanggan (Kelly et al., 2010). Komponen-komponen social media marketing meliputi interaction, sharing of content, online communities, accessibility dan credibility (Babac, 2011; Fischer \& Reuber, 2011; Taprial \& Kanwar, 2012).

\section{Customer Engagement}

Customer engagement adalah kegiatan yang secara tidak langsung melibatkan konsumen untuk pencarian, evaluasi alternatif, dan pengambilan keputusan yang melibatkan pemilihan brand (Vivek et al., 2014). Customer engagement sangat penting dalam menghasilkan kinerja perusahaan yang lebih tinggi termasuk pertumbuhan penjualan, keuntungan kompetitif yang lebih baik dan keuntungan (Poorrezaei, 2016).

Customer engagement diakui sebagai hubungan emosional antara perusahaan dan pelanggannya yang berfokus pada interkasi dengan pelanggan dan partisipasi teknologi informasi dan komunikasi yang memberikan peluang untuk bertukar pengetahuan (Vivek, 2009). Customer engagement dibentuk melalui tujuh tahapan yaitu koneksi, interaksi, kepuasan, retensi, komitmen, advokasi, dan keterlibatan (Muchardie et al., 2016). Komponen-komponen dalam customer engagement yaitu entusaism, attention, absorption, interaction dan identification (So et al., 2014).

\section{Loyalitas Merek}

Loyalitas merek diartikan sebagai preferensi konsumen yang konsisten untuk melakukan pembelian atas merek yang sama pada produk tertentu atau kategori layanan tertentu (Schiffman \& Kanuk, 2004). Selain itu, loyalitas merek menjadi ukuran hubungan pelanggan ke merek (Durianto et al., 2004). Loyalitas dianggap sebagai indikator signifikan dari kesuksesan pemasaran suatu perusahaan. Loyalitas merek terbentuk karena adanya peran utama pengalaman pelanggan saat mengkonsumsi layanan dari perusahaan (So et al., 2014).

Loyalitas merek berperan penting karena dapat menghasilkan hambatan bagi pesaing untuk masuk, menghindari ancaman kompetitif dari pesaing, meningkatkan penjualan dan pendapatan serta menurunkan sensitifvitas harga pelanggan (Delgado-Ballerster \& Munuera-Aleman, 2005; Rowley, 2015). Komponen-komponen loyalitas merek meliputi pembelian ulang secara teratur, merekomendasikan produk, kekebalan terhadap pesaing (Delgado-Ballerster \& Munuera-Aleman, 2005).

\section{Kepercayaan}

Kepercayaan adalah semua pengetahuan yang dimiliki konsumen dan semua kesimpulan yang dibuat konsumen tentang objek, atribut, dan manfaatnya (Sunarto, 2009). Objek berupa produk, orang, dan perusahaan di mana seseorang memiliki kepercayaan dan sikap. Atribut berupa karakteristik atau fitur yang mungkin dimiliki atau tidak dimiliki oleh objek. Sedangkan manfaat berupa hasil positif yang diberikan atribut kepada konsumen. Komponen-komponen kepercayaan meliputi integritas, kebajikan dan kompetensi (Jasfar, 2009).

\section{Hubungan antar Variabel}

Pengaruh social media marketing terhadap customer engagement. Hasil penelitian menunjukkan bahwa social media marketing memiliki pengaruh yang positif dan signifikan terhadap customer 
Rachmadhaniyati dan Sanaji. Pengaruh Social Media Marketing terhadap Customer Engagement dengan Loyalitas Merek dan Kepercayaan sebagai Variabel Mediasi

engagement maupun loyalitas merek (Muchardie et al., 2016). Selain itu, dalam penelitian lain social media marketing memiliki pengaruh yang signifikan terhadap customer engagement (Utami \& Saputri, 2020). Jenis postingan konten dalam sosial media memberikan pengaruh yang signifikan pada customer engagement. Semakin tinggi pengaruh sosial media marketing, semakin tinggi pula customer engagement (Farook \& Abeysekara, 2016).

H1: Social media marketing berpengaruh positif terhadap customer engagement.

Bilgin, (2018) aktivitas social media marketing merupakan faktor yang efektif terhadap citra dan loyalitas merek. Social media marketing berpengaruh signifikan terhadap loyalitas merek pada industry fashion (Salem \& Salem, 2019). Selain itu, ditemukan hasil lain bahwa customer engagement dan social media marketing berpengaruh signifikan terhadap loyalitas merek, dan customer engagement terbukti memediasi hubungan tidak langsung social media marketing terhadap loyalitas (Utami \& Saputri, 2020).

H2: Social media marketing berpengaruh positif terhadap loyalitas merek.

Zulfikar (2017) menunjukkan social media marketing berpengaruh positif dan signifikan terhadap brand trust. Upaya social media marketing termasuk situs web yang jelas, alat media sosial yang aktif dan terbaru, keamanan situs pada loyalitas dan kepercayaan. Sehingga menunjukkan hasil penelitian bahwa terdapat pengaruh positif dari upaya tersebut terhadap kepercayaan dan pengaruh kepercayaan terhadap loyalitas (Tatar, Sahika, 2016).

H3: Social media marketing berpengaruh positif terhadap kepercayaan.

Peran mediasi dari customer engagement dan interaktivitas sosial pada loyalitas merek menunjukkan bahwa terdapat hubungan signifikan dan positif dan ini membantu dalam membuat keputusan atas praktek kerja sehari-hari dan mengembangkan sikap dan persepsi konsumen terhadap suatu merek (Ting et al., 2020). Customer engagement memiliki pengaruh yang lebih besar terhadap loyalitas merek dibandingkan social media marketing (Muchardie et al., 2016). Namun, loyalitas merek dapat diperkuat tidak hanya melalui pengalaman konsumtif tetapi juga melalui customer engagement (So et al., 2014). Persepsi nilai berpengaruh positif dan signifikan terhadap customer engagement, dengan begitu semakin tinggi perspsi nilai dari konsumen terhadap produk yang ditawarkan di media sosial maka semakin tinggi juga keinginan konsumen untuk terlibat dalam aktivitas customer engagement yang dilakukan perusahaan dengan menyukai, membagikan atau berkomentar di media sosial (Purnami \& Kusuma, 2017).

H4: Loyalitas merek berpengaruh positif terhadap customer engagement.

Dalam era sekarang ini, niat beli dan sikap loyalitas konsumen kepada perusahaan sangat dipengaruhi oleh kepercayaan konsumen (Veno \& Subagio, 2013). Hal ini dapat dijelaskan bahwa terdapat hubungan positif yang signifikan antara kepercayaan dengan customer engagement. Semakin tinggi kepercayaan maka semakin tinggi customer engagement (Sukamdewi \& Prihatsanti, 2018). Selain itu, ditemukan juga kepercayaan secara signifikan memengaruhi customer engagement dengan kepercayaan pada penyedia layanan dan kepercayaan pada regulator yang mendorong tingkat customer engagement yang lebih tinggi (Agyei et al., 2020).

H5: Kepercayaan berpengaruh positif terhadap customer engagement.

Berdasarkan hubungan antar variabel, model penelitian ditunjukkan pada gambar 1 .

\section{METODE PENELITIAN}

Penelitian ini menggunakan metode penelitian kuantitatif. Populasi penelitian ini adalah semua pelaku online shop yang jumlahnya tidak diketahui secara pasti. Teknik sampling yang digunakan adalah 
purposive sampling dengan kriteria responden minimal usia 16 tahun, pengguna aktif media sosial dan pernah berbelanja online. Analisis dan pengolahan data menggunakan metode statistic dengan Partial Least Square (PLS) guna mempredisksi model path yang bisa digunakan untuk model yang kompleks dan meliputi banyak variabel. Model statistik ini dibantu dengan software SmartPLS 3.0. Variabel dalam penelitian ini ada tiga, yaitu variabel independen, dependen, dan mediasi. Variabel independen dalam penelitian ini adalah social media marketing. Variabel dependen dalam penelitian ini adalah customer engagement. Variabel mediasi dalam penelitian ini adalah loyalitas merek dan kepercayaan. Jumlah sampel dalam penelitian ini yaitu 200 responden yang memenuhi kriteria tersebut.

Sumber data yang digunakan adalah data primer dan data sekunder. Data primer diperoleh dari pengumpulan data yang disusun menggunakan google form dan disebarkan melalui whatsapp, instagram, dan line kepada responden pengguna marketplace seperti Shopee, Bukalapak, Tokopedia, Lazada, dan Blili. Sedangkan data sekunder diperoleh dari buku, karya ilmiah, dan jurnal. Penelitian ini menggunakan instrumen kuesioner di mana item pertanyaan dalam variabel social media marketing merujuk pada online communities, interaction, sharing of content, accessibility, dan credibility (Taprial \& Kanwar, 2012; Fischer \& Reuber, 2011; Babac, 2011). Customer engagement merujuk pada enthusiasm, attention, absorption, interaction dan identification (So et al., 2014). Loyalitas merek merujuk pada pembelian ulang secara teratur, merekomendasikan produk, kekebalan terhadap pesaing (Delgado-Ballerster \& Munuera-Aleman, 2005). Kepercayaan merujuk pada integritas, kebajikan, dan kompetensi (Jasfar, 2009). Masing-masing item pertanyaan dari social media marketing, customer engagement, loyalitas merek dan kepercayaan ini diancang menggunakan teknik penskalaan Likert lima point dari "sangat tidak setuju" nilai 1 sampai "sangat setuju" nilai 5.

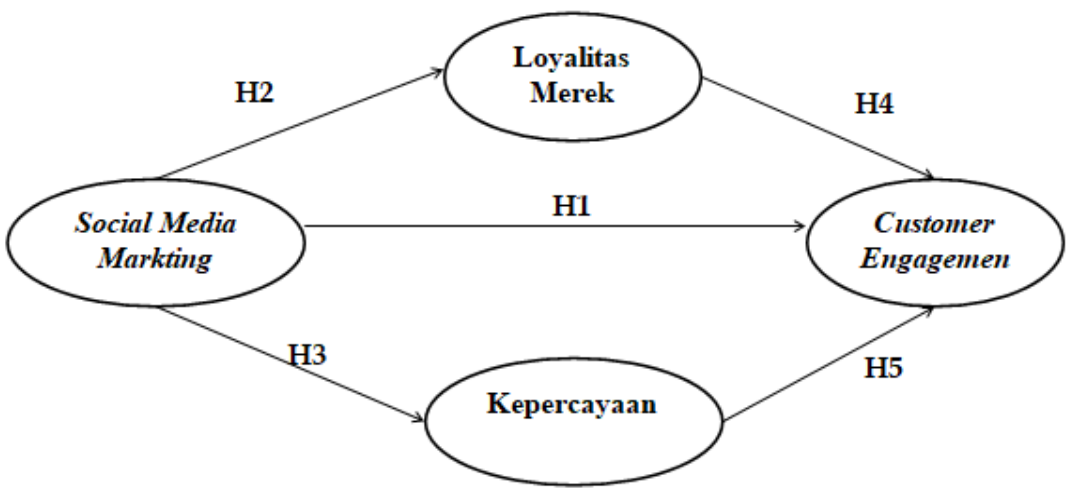

Gambar 1. MODEL PENELITIAN

\section{HASIL DAN PEMBAHASAN}

\section{Karakteristik Responden}

Pada penelitian ini, diperoleh total 200 responden yang telah dinyatakan layak dan memenuhi kriteria. Responden merupakan pelaku online shop yang menggunakan media sosial untuk berbelanja online. Dari data tersebut diketahui mayoritas responden merupakan perempuan yakni sebanyak 133 orang (66,5\%), usia responden kisaran 21-25 tahun sebanyak 156 orang (78\%). Sebagian besar responden adalah pelajar/mahasiswa sebanyk 137 orang $(68,5 \%)$ dengan pendidikan terakhir SMA/SMK sederajat sebanyak 121 orang $(60,5 \%)$ dan penghasilan per bulan responden kisaran $<\mathrm{Rp} 1.000 .000$ sebanyak 103 orang $(51,5 \%)$ dan mayoritas toko online yang sering dikunjungi responden yaitu tentang pakaian dan aksesoris sebanyak 107 orang $(53,5 \%)$.

\section{Uji Validitas}

Uji validitas digunakan untuk melihat seberapa baik suatu instrument penelitian dapat digunakan untuk mengukur konsep tertentu. Dua jenis validitas digunakan pada penelitian ini, validitas 
konvergen dan validitas diskriminan. Validitas konvergen terpenuhi, jika outer loading $>0,5$ dan average variance extracted (AVE) $>0,5$ (Wong, 2013). Pada tahap awal analisis, ditemukan ada beberapa item yang tidak valid yaitu item marketplace "mudah diakses kapan saja" dan "di mana saja" dari variabel social media marketing memiliki loading < 0,5, dan item "melupakan semua aktivitas" dan "mengkritisi merasa terhina" dari variabel customer engagement memiliki loading $<0,5$. Item-item yang tidak valid tersebut dikeluarkan untuk analisis selanjutnya. Hasil analisis berikutnya, seluruh indikator mempunyai outer loading lebih tinggi dari 0,5 dan AVE > 0,5, sehingga item pernyataan tersebut dapat dikatakan valid.

Uji validitas diskriminan menggunakan kriteria cross loading lebih rendah dari outer loading dan akar kuadrat AVE lebih besar dari korelasi antar variabel (Chin, 1998). Fornell \& Larcker dalam Wong (2013) mengemukakan bahwa akar kuadrat dari AVE di setiap variabel laten dapat digunakan untuk menguji discriminant validity, jika nilai ini lebih besar dari nilai korelasi lain di antara variabel laten atau indikator dikatakan memenuhi discriminant validity jika nilai cross loading indikator terhadap variabelnya adalah yang terbesar dibandingkan variabel lainnya.

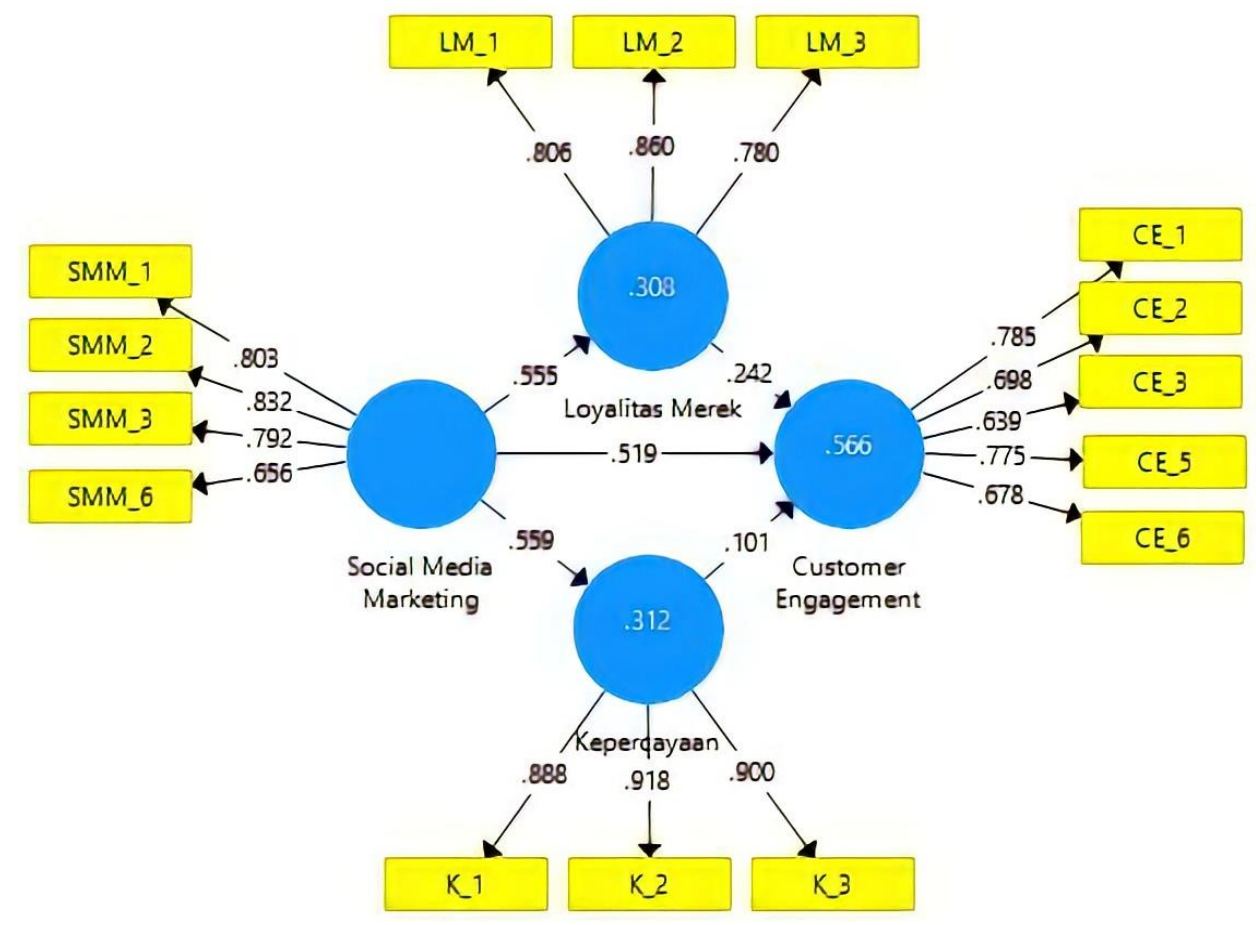

Sumber: Output SmartPLS3 (data diolah penulis, 2021)

Gambar 2. MODEL STRUKTURAL (OUTER MODEL)

Tabel 1, nilai AVE customer engagement adalah 0.514 dan akar kuadratnya sebesar 0.717. AVE kepercayaan adalah 0.814 dengan akar kuadrat sebesar 0.902. AVE loyalitas merek adalah 0.666 dengan akar kuadrat sebesar 0.816 dan AVE social media marketing adalah 0.599 dengan akar kuadrat sebesar 0.774. Angka hasil kuadrat AVE ini lebih besar dari nilai korelasi dengan variabel lainnya dalam model, maka validitas diskriminan terpenuhi.

\section{Uji Reliabilitas}

Uji reliabilitas digunakan untuk menunjukkan bahwa instrumen penelitian dapat dihandalkan atau reliabel. Dalam penelitian ini reliabilitas dilihat dari hasil uji komposit dan nilai Cronbach's alpha pada semua variabel. Suatu instrument dapat dikatakan reliabel jika memiliki nilai composite reliability dan Cronbach's alpha >0,70 (Ghozali \& Latan, 2015). Hasil setelah item yang tidak valid dikeluarkan menunjukkan keandalan hasil uji komposit dan Cronbach's alpha memiliki nilai yang baik. Hal tersebut dikarenakan semua variabel laten mempunyai composite reliability dan Cronbach's alpha $>0,70$. Jadi semua variabel dalam penelitian ini adalah variabel laten. 
Tabel 1.

HASIL UJI VALIDITAS DAN RELIABILITIAS

\begin{tabular}{|c|c|c|c|c|}
\hline No & Pernyataan & $\begin{array}{l}\text { Cronbach's } \\
\text { Aplha }\end{array}$ & $\begin{array}{l}\text { Composite } \\
\text { Reliability }\end{array}$ & $\begin{array}{c}\text { Average Variance } \\
\text { Extracted }(A V E)\end{array}$ \\
\hline \multicolumn{5}{|c|}{ Social Media Marketing } \\
\hline 1 & Mudah membangun hubungan & \multirow{4}{*}{0,774} & \multirow{4}{*}{0,856} & \multirow{4}{*}{0,599} \\
\hline 2 & Mudah berinteraksi & & & \\
\hline 3 & Mudah berbagi konten & & & \\
\hline 4 & Informasi dapat dipercaya & & & \\
\hline \multicolumn{5}{|c|}{ Customer Engagement } \\
\hline 1 & Bersemangat mendapatkan informasi produk/layanan & \multirow{5}{*}{0,763} & \multirow{5}{*}{0,840} & \multirow{5}{*}{0,514} \\
\hline 2 & Mencermati informasi berasal & & & \\
\hline 3 & Berkomentar terhadap perkembangan produk/layanan & & & \\
\hline 4 & Aktif berbagi informasi & & & \\
\hline 5 & Memuji merasa terpuji & & & \\
\hline \multicolumn{5}{|c|}{ Loyalitas Merek } \\
\hline 1 & Membeli ulang & \multirow{3}{*}{0,750} & \multirow{3}{*}{0,856} & \multirow{3}{*}{0,666} \\
\hline 2 & Merekomendasikan kepada orang lain & & & \\
\hline 3 & Menjadi pilihan pertama ketika berbelanja & & & \\
\hline \multicolumn{5}{|c|}{ Kepercayaan } \\
\hline 1 & Memenuhi janji & \multirow{3}{*}{0,886} & \multirow{3}{*}{0,929} & \multirow{3}{*}{0,814} \\
\hline 2 & Memberikan perlakuan baik & & & \\
\hline 3 & Memberikan layanan belanja online sesuai harapan & & & \\
\hline
\end{tabular}

Sumber: Data diolah (2021)

Uji Kelayakan Model (Goodness of Fit)

Uji ini dilakukan untuk mengetahui variabel independent dalam menjelaskan variasi yang terjadi pada variabel dependen. Uji kelayakan model ditunjukkan dengan melihat nilai GoF dan nilai $r$-square yang diperoleh dari hasil pengujian di program SmartPLS 3 (Ghozali \& Latan, 2015). Nilai GoF dapat diperoleh dengan menghitung akar kuadrat nilai rata-rata jumlah terbobot dikalikan dengan nilai ratarata nilai $\mathrm{R}^{2}$ (Ghozali \& Latan, 2015) Rumus (1) untuk mencari nilai GoF.

$$
\begin{aligned}
\text { GoF } & =\sqrt{\text { rata }- \text { rata jumlah terbobot } \times \mathrm{R}^{2}} \\
& =\sqrt{0,855 \times 0,395} \\
& =0,581
\end{aligned}
$$

Perhitungan rumus di atas memeroleh nilai GoF sebesar 0,581, berarti model pengukuran dan model struktural dalam penelitian ini termasuk kategori GoF Large.

Tabel 2.

NILAI R-SQUARE

\begin{tabular}{lccccc}
\hline Latent Variabel & $\begin{array}{c}\text { Jumlah } \\
\text { Indikator }\end{array}$ & AVE & $\begin{array}{c}\text { Jumlah } \\
\text { Terbobot }\end{array}$ & $\mathbf{R}^{\mathbf{2}}$ & $\begin{array}{c}\text { Global } \\
\text { Gof }\end{array}$ \\
\hline Social Media Marketing & 4 & 0.599 & 2,396 & & \\
Customer Engagement & 5 & 0.514 & 2,570 & 0.566 & \\
Loyalitas Merek & 3 & 0.666 & 1,998 & 0.308 & \\
Kepercayaan & 3 & 0.814 & 2,442 & 0.312 & \\
Total & 11 & & 9,406 & 1.186 & \\
Average & & & 0,855 & 0,395 & 0,581 \\
\hline Sul
\end{tabular}

Sumber: Data diolah (2021) 
Rachmadhaniyati dan Sanaji. Pengaruh Social Media Marketing terhadap Customer Engagement dengan Loyalitas Merek dan Kepercayaan sebagai Variabel Mediasi

Berdasarkan tabel 2, pengaruh social media marketing terhadap customer engagement memberikan nilai $\mathrm{R}^{2}$ sebesar 0,566 . Diinterpretasikan bahwa variabel customer engagement yang dapat dijelaskan oleh variabel social media marketing sebesar 55,6\%, sedangkan 44,4\% dijelaskan oleh variabel lain di luar model penelitian. Model pengaruh social media marketing terhadap loyalitas merek memberikan nilai $\mathrm{R}^{2}$ sebesar 0,308 yang diinterpretasikan bahwa variabel loyalitas merek dapat dijelaskan oleh variabel social media marketing dan customer engagement sebesar 30,8 \% sedangkan 69,2\% dijelaskan oleh variabel lain di luar model. Pengaruh social media marketing terhadap kepercayaan memberikan nilai $\mathrm{R}^{2}$ sebesar 0,312 yang diinterpretasikan bahwa variabel kepercayaan dapat dijelaskan oleh social media marketing, customer engagement, dan loyalitas sebesar $31,2 \%$ sedangkan $68,8 \%$ dijelaskan oleh variabel lain di luar model penelitian.

\section{Uji Hipotesis}

Pengujian hipotesis menggunakan fitur bootstrapping pada software SmartPLS 3.0. Hipotesis diterima jika level of significant $\alpha=0,05$ atau $\mathrm{p}$-value $<0,05$ dan nilai t-statistic melihat $\mathrm{t}$-tabel pada alpha 0,05 $(5 \%)=1,96($ Ghozali \& Latan, 2015).

\section{Tabel 3.}

\section{HASIL UJI HIPOTESIS}

\begin{tabular}{|c|c|c|c|c|c|c|}
\hline $\begin{array}{c}\text { Hubungan Antar } \\
\text { Variabel }\end{array}$ & Hipotesis & $\begin{array}{c}\text { Original } \\
\text { Sample }\end{array}$ & St. Dev & $\begin{array}{c}T- \\
\text { Statistics }\end{array}$ & P-Values & Keterangan \\
\hline $\begin{array}{l}\text { Social Media Marketing } \rightarrow \\
\text { Customer Engagement }\end{array}$ & H1 & 0.519 & 0.071 & 7.321 & 0,000 & Signifikan \\
\hline $\begin{array}{l}\text { Social Media Marketing } \\
\rightarrow \text { Loyalitas Merek }\end{array}$ & $\mathrm{H} 2$ & 0.555 & 0.058 & 9.537 & 0,000 & Signifikan \\
\hline $\begin{array}{l}\text { Social Media Marketing } \rightarrow \\
\text { Kepercayaan }\end{array}$ & H3 & 0.559 & 0.049 & 11.292 & 0,000 & Signifikan \\
\hline $\begin{array}{lc}\text { Loyalitas } & \text { Merek } \\
\text { Customer Engagement }\end{array} \rightarrow$ & $\mathrm{H} 4$ & 0.242 & 0.073 & 3.33 & 0.001 & Signifikan \\
\hline $\begin{array}{l}\text { Kepercayaan } \rightarrow \text { Customer } \\
\text { Engagement }\end{array}$ & H5 & 0.101 & 0.082 & 1.231 & 0.219 & $\begin{array}{c}\text { Tidak } \\
\text { Signifikan }\end{array}$ \\
\hline
\end{tabular}

Sumber: Data diolah (2021)

Hasil uji hipotesis menunjukkan bahwa social media marketing memiliki pengaruh positif terhadap customer engagement. Nilai p-values $0,000<0,05$ mengindikasikan bahwa H1 diterima. Sementara itu, social media marketing mempunyai pengaruh positif terhadap loyalitas merek. Nilai $p$-values $0,000<0,05$ mengindikasikan bahwa $\mathrm{H} 2$ diterima. Kemudian, social media marketing mempunyai pengaruh positif terhadap kepercayaan. Nilai p-values $0,000<0,05$ mengindikasikan bahwa $\mathrm{H} 3$ diterima. Selanjutnya, loyalitas merek memiliki pengaruh positif terhadap customer engagement. Nilai p-values $0,001<0,05$ mengindikasikan bahwa H4 diterima. Namun, hasil uji hipotesis menunjukkan bahwa kepercayaan tidak mempunyai pengaruh terhadap customer engagement. Nilai p-values $0,219>$ 0,05 maka H5 ditolak.

\section{Pengaruh Social Media Marketing terhadap Customer Engagement}

Hasil penelitian ini membuktikan bahwa social media marketing berpengaruh positif dan signifikan terhadap customer engagement dalam berbelanja online. Hal ini ditunjukkan oleh hasil uji hipotesis yang mengindikasikan H1 diterima. Perubahan pada social media marketing dapat menyebabkan perubahan pada customer engagement. Media sosial dan jenis postingan konten memberikan pengaruh yang signifikan pada customer engagement. Semakin tinggi pengaruh social media marketing, semakin tinggi pula customer engagement. (Farook \& Abeysekara, 2016).Karena promosi yang dilakukan marketplace dapat memengaruhi dalam pengambilan keputusan untuk suatu brand. Social media marketing yang dilakukan yaitu dengan memanfaatkan marketplace seperti Shopee, Bukalapak, Tokopedia, Lazada untuk memasarkan produk agar konsumen tertarik untuk mendapatkan produk dari marketplace tersebut. 
Hasil ini sejalan dengan Muchardie et al. (2016) yang menyatakan social media marketing memiliki pengaruh positif dan signifikan terhadap customer engagement. Hasil ini sejalan dengan Weinberg, (2009) promosi melalui situs web, produk, atau layanan melalui media sosial berpeluang besar untuk menjalin hubungan antara pemasar dan konsumen. Artinya, semakin marketplace melakukan komunikasi dengan memanfaatkan media sosial, maka akan semakin terlibat dalam brand marketplace tersebut.

\section{Pengaruh Social Media Marketing terhadap Loyalitas Merek}

Hasil penelitian ini membuktikan bahwa social media marketing mempunyai pengaruh positif dan signifikan terhadap loyalitas merek dalam berbelanja online. Hal ini ditunjukkan oleh hasil uji hipotesis yang mengindikasikan $\mathrm{H} 2$ diterima. Media sosial membantu perusahaan untuk membangun loyalitas merek melalui jaringan, percakapan dan membangun komunitas (Purnomo \& Isharina, 2013). Artinya, apabila loyalitas merek tetap dijaga dengan baik maka akan menimbulkan profit jangka panjang bagi perusahaan (Kiyani et al., 2012).

Hasil ini sejalan dengan Bilgin (2018) bahwa social media marketing sebagai faktor yang efektif terhadap citra merek dan loyalitas merek. Aktivitas social media marketing yang paling signifikan yaitu hiburan. Selain itu, Salem \& Salem (2019) bahwa social media marketing berpengaruh signifikan terhadap loyalitas merek pada industri fashion. Fashion menjadi salah satu pilihan marketplace yang sering dikunjungi oleh konsumen. Di mana hasil penelitian ini menunjukkan mayoritas responden adalah wanita dan jenis toko yang sering dikunjungi adalah pakaian dan aksesoris. Kesetiaan konsumen terhadap brand akan membuat konsumen semakin terlibat karena konsistensi yang dipegang dalam memenuhi kepuasan konsumen, kualitas produk yang diterima konsumen sesuai dengan harapan (Yunaida, 2017). Hal ini mendukung Amalia (2016) yang menejelaskan jika social media marketing semakin baik dikelola maka loyalitas merek akan semakin meningkat. Oleh karena itu, loyalitas dianggap sebagai indikator yang signifikan terhadap kesuskesan suatu perusahaan.

\section{Pengaruh Social Media Marketing terhadap Kepercayaan}

Hasil uji hipotesis dalam penelitian ini menunjukkan social media marketing mempunyai pengaruh positf dan signifikan terhadap kepercayaan dalam berbelanja online. Hal ini ditunjukkan oleh hasil uji hipotesis yang mengindikasikan $\mathrm{H} 3$ diterima. Kepercayaan muncul karena keyakinan pelanggan yang muncul dari persepsi yang berulang dan adanya pembelajaran serta pengalaman positif (So et al., 2014). Bukti ini ditunjukkan dengan pertanyaan nomor 17 di mana responden cenderung setuju. Kepercayaan mengembangkan lingkungan online yang memungkinkan kolaborasi antara berbagai pihak dan membantu konsumen dalam membuat keputusan bijak (Haslim \& Tan, 2015). Oleh karena itu, konsumen enggan membeli produk pada marketplace apabila tidak memberikan pengalaman positif.

Hasil ini sejalan dengan Bilgin (2018) bahwa aktivitas social media marketing merupakan faktor efektif terhadap citra dan loyalitas merek. Upaya social media marketing termasuk situs web yang jelas, alat media sosial yang aktif dan terbaru, keamanan situs pada loyalitas dan kepercayaan. Sehingga menunjukkan terdapat pengaruh positif dari upaya tersebut terhadap kepercayaan dan pengaruh kepercayaan terhadap loyalitas (Tatar, Sahika, 2016). Artinya, banyak brand yang melakukan upaya tersebut untuk mendapatkan pelanggan baru agar tetap bertahan di lingkungan marketplace online.

\section{Pengaruh Loyalitas Merek terhadap Customer Engagement}

Hasil penelitian ini menunjukkan loyalitas merek memiliki pengaruh yang positif dan signifikan terhadap customer engagement dalam berbelanja online pada marketplace. Hal ini ditunjukkan oleh hasil uji hipotesis yang mengindikasikan $\mathrm{H} 4$ diterima. Bukti ini ditunjukkan dengan pertanyaan nomor 18 di mana responden cenderung setuju terhadap kesesuaian rekomendasi. Loyalitas merek hal yang sangat penting dalam pemasaran di mana memperlihatkan adanya hubungan antar pelanggan dengan 
merek ditandai dengan pembelian ulang. Artinya, secara tidak langsung konsumen dapat membangun hubungan yang kuat dengan perusahaan (Utami \& Saputri, 2020).

Hal ini sejalan dengan Ting et al., (2020) yaitu peran mediasi dari customer engagement dan interaktivitas sosial pada loyalitas merek menunjukkan bahwa terdapat hubungan signifikan dan positif yang dapat membantu dalam membuat keputusan, serta mengembangkan sikap dan persepsi konsumen terhadap suatu merek. Persepsi nilai berpengaruh positif dan signifikan terhadap customer engagement, dengan begitu semakin tinggi persepsi nilai dari konsumen terhadap produk yang ditawarkan di media sosial maka semakin tinggi juga keinginan konsumen untuk terlibat dalam aktivitas customer engagement yang dilakukan perusahaan dengan menyukai, membagikan atau berkomentar di media sosial (Purnami, 2017).

\section{Pengaruh Kepercayaan terhadap Customer Engagement}

Hasil uji hipotesis dalam penelitian menunjukkan kepercayaan tidak memiliki pengaruh terhadap customer engagement ketika berbelanja online. Hal ini ditunjukkan oleh hasil uji hipotesis yang mengindikasikan H5 ditolak. Bukti ini ditunjukkan dengan pertanyaan nomor 19 di mana responden cenderung tidak setuju dan netral terhadap kesesuaian harapan konsumen. Kepercayaan tidak muncul secara tiba-tiba, tetapi harus dibangun sejak awal. Kepercayaan merupakan penggerak dalam suatu hubungan yang efektif (Veno \& Subagio, 2013) Oleh karena itu, tinggi rendahnya kepercayaan konsumen terhadap brand tidak serta merta mendorong terjadinya pengambilan keputusan seseorang untuk berbelanja.

Hasil ini tidak sejalan dengan Agyei et al. (2020) yang menyatakan kepercayaan secara signifikan memengaruhi customer engagement di mana kepercayaan pada penyedia layanan mendorong customer engagement yang lebih tinggi. Kepercayaan konsumen terhadap tenaga penjual akan berpengaruh terhadap kepercayaan marketplace. Konsumen bersedia bekerja sama dengan kepercayaannya terhadap marketplace karena keandalan tenaga penjual yang terwujud (Veno \& Subagio, 2013). Oleh karena itu, penelitian yang tidak sejalan ini terjadi, karena marketplace memberikan layanan yang kurang baik dan tidak memenuhi janji.

\section{KESIMPULAN}

Berdasarkan hasil uji hipotesis, kepercayaan tidak memiliki pengaruh terhadap customer engagement pada online shop. Namun, social media marketing terbukti berpengaruh positif terhadap customer engagement, loyalitas merek, dan kepercayaan pada online shop. Loyalitas merek mempunyai pengaruh terhadap customer engagement pada online shop akan memiliki rasa cinta terhadap marketplace tersebut, sehingga para pengguna aktif sosial media khususnya online shop akan tetap melakukan pembelian online.

Social media marketing juga berpengaruh positif terhadap loyalitas merek online shop. Hasil tersebut membuktikan pentingnya loyalitas pelanggan terhadap marketplace sebagai salah satu faktor perkembangan marketplace. Oleh karena itu, penelitian ini dapat dijadikan acuan untuk perusahaanperusahaan terhadap strategi pemasaran, akses penggunaan, responsive terhadap perkembangan lingkungan, pemenuhan janji dan kesesuaian deskriptif yang dapat memengaruhi perusahaan sehingga perusahaan tidak mengalami penurunan konsumen dan perusahaan memiliki keunggulan dari masingmasing perusahaan.

Disarankan kepada penelitian selanjutnya untuk memerdalam pernyataan pada kuesioner terkait social media marketing, customer engagement, loyalitas merek dan kepercayaan. Khususnya pada variabel social media marketing dan customer engagement, di mana masih terdapat item penyataan yang tidak valid. Penelitian ini juga perlu ditindaklanjuti untuk memeroleh penjelasan lebih lanjut tentang hubungan kepercayaan terhadap customer engagement dari online shop. Untuk lebih memerkuat hasil penelitian, penelitian selanjutnya dapat melakukan penelitian secara offline dan menambah jumlah responden, karena pada penelitian ini jumlah sampel yang relatif kecil (200 responden) menjadikan keterbatasan penelitian. 


\section{DAFTAR PUSTAKA}

Agyei, J., Sun, S., Abrokwah, E., Penney, E. K., \& Ofori-Boafo, R. (2020). Influence of Trust on Customer Engagement: Empirical Evidence From the Insurance Industry in Ghana. SAGE Open, 10(1). https://doi.org/10.1177/2158244019899104

Amalia, A. (2016). Pengaruh Social Media Marketing terhadap Brand Loyalty dengan Brand Trust sebagai Variabel Intervening (Studi Pada Follower Twitter Mizone @ Mizoneid). Jurnal Ilmu Manajemen (JIM), 4(3), 1-12.

Babac, R. (2011). Impact of Social Media Use on Brand Equity of Magazine Brands. In International Marketing (Vol. 15). https://www.diva-portal.org/smash/get/diva2:430935/FULLTEXT01.pdf

Bilgin, Y. (2018). The Effect of Social Media Marketing Activities on Brand Awareness, Brand Image and Brand Loyalty. Business \& Management Studies: An International Journal, 6(1), 128-148. https://doi.org/10.15295/bmij.v6i1.229

Bowden, J. (2009). The Process of Customer Engagement: A Conceptual Framework. Journal of Marketing Theory and Practice, 17(1), 63-74. https://doi.org/10.2753/MTP1069-6679170105

Chin, W. W. (1998). The Partial Least Squares Approach for Structural Equation Modeling. In Modern Methods for Business Research (Issue 1998). New Jersey London: Lawrence Erlbaum Associates.

Daeng, I. T. M., Mewengkang, N. ., \& Kalesaran, E. R. (2017). Penggunaan Smartphone dalam Menunjang Aktivitas Perkuliahan oleh Mahasiswa Fispol Unsrat Manado. E-Journal "Acta Diurna," 6(1), 1-15.

Delgado-Ballerster, E., \& Munuera-Aleman, J. L. (2005). Does Brand Trust Matter to Brand Equity? Journal of Product and Brand Management, 14(3), 187-196. https://doi.org/https://doi.org/10.1108/10610420510601058

Dissanayake, D. M. R., Siriwardana, A., \& Ismail, N. (2019). Social Media Marketing and Customer Engagement: A Review on Concepts and Empirical Contributions. Kelaniya Journal of Management, $8(1), 71$. https://doi.org/10.4038/kjm.v8i1.7592

Durianto, D., Budiman, L. J., \& Sugiarto. (2004). Brand Equity Ten Strategi Memimpin Pasar. Jakarta: Gramedia Pustaka Utama.

Farook, F. S., \& Abeysekara, N. (2016). Influence of Social Media Marketing on Customer Engagement. International Journal of Business and Management Invention, 5(12), 115-125. www.ijbmi.org

Fischer, E., \& Reuber, A. R. (2011). Social Interaction Via New Social Media: (How) Can Interactions on Twitter Affect Effectual Thinking and Behavior? Journal of Business Venturing, 26(1), 1-18. https://doi.org/10.1016/j.jbusvent.2010.09.002

Ghozali, I., \& Latan, H. (2015). Partial Least Squares : Konsep, Teknik dan Aplikasi Menggunakan Program Smartpls 3.0 untuk Penelitian Empiris. Semarang: Badan Penerbit UNDIP.

Hannief, S. M., \& Martini, E. (2018). The Impact of Social Media Marketing Instagram on Customer Brand Loyalty at Warunk Upnormal. E-Proceeding of Management, 5(1), 377-390. https://openlibrarypublications.telkomuniversity.ac.id/index.php/management/article/view/6380 /6358 
Rachmadhaniyati dan Sanaji. Pengaruh Social Media Marketing terhadap Customer Engagement dengan Loyalitas Merek dan Kepercayaan sebagai Variabel Mediasi

Haslim, K. F., \& Tan, F. B. (2015). The Mediating Role of Trust and Commitment on Members' Continuous Knowledge Sharing Intention: A Commitment-Trust Theory Perspective. International Journal of Information Management, 35(2), 145-151. https://doi.org/10.1016/j.ijinfomgt.2014.11.001

Hidayah, A. (2019). Pengaruh Social Media Marketing terhadap Brand Loyalty melalui Customer Engagement pada Wardah Cosmetics (Studi pada Pengikut Akun Instagram @ wardahbeauty). $\begin{array}{lllll}\text { Jurnal Ilmiah Mahasiswa } & \text { FEB, }\end{array}$ https://jimfeb.ub.ac.id/index.php/jimfeb/article/download/5514/4851

Imron, A. S., Wardani, N. H., \& Rokhmawati, R. I. (2018). Analisis Pengaruh Pemasaran Media Sosial terhadap Loyalitas Konsumen: Studi pada Transportasi Online (Go-Jek Indonesia). Jurnal Pengembangan Teknologi Informasi Dan Ilmu Komputer, 2(9), 2570-2578. http://jptiik.ub.ac.id

Ishak, A., \& Luthfi, Z. (2011). Pengaruh Kepuasan dan Kepercayaan Konsumen terhadap Loyalitas : Studi Tentang Peran Mediasi Switching Costs. Jurnal Siasat Bisnis, 15(1), 55-66.

Jasfar, F. (2009). Manajemen Jasa : Pendekatan Terpadu. Bogor: Ghalia Indonesia.

Juju, D., \& Studio, M. (2013). Hosting dan Sharing Foto Video dengan Photobucket. Jakarta: Elex Media Komputindo.

Kelly, L., Kerr, G., \& Drennan, J. (2010). Avoidance of Advertising in Social Networking Sites. Journal of Interactive Advertising, 10(2), 16-27. https://doi.org/https://doi.org/10.1080/15252019.2010.10722167

Kiyani, T. M., Niazi, M. R., \& Niazi, R. A. (2012). The Relationship between Brand Trust, Customer Satisfaction and Customer Loyalty (Evidence from automobile sector of Pakistan). Interdisciplinary Journal of Contemporary Research in Business, 4(1), 489-502.

Kotler, P., \& Armsttrong, G. (2011). Prinsip-Prinsip Pemasaran. Jakarta: Erlangga.

Kristianto, P. H., \& Juanedi, M. S. (2013). Peran Kepercayaan Merek sebagai Variabel Mediasi antara Karakteristik dengan Loyalitas Merek Produk Cinderamata Dagadu Djokdja. Journal of Chemical Information and Modeling, 53(9), 1689-1699.

Laksamana, P. (2018). Impact of Social Media Marketing on Purchase Intention and Brand Loyalty: Evidence from Indonesia's Banking Industry. EconJournals, 8(1), 13-18.

Muchardie, B. G., Yudiana, N. H., \& Gunawan, A. (2016). Effect of Social Media Marketing on Customer Engagement and its Impact on Brand Loyalty in Caring Colours Cosmetics, Martha Tilaar. Binus Business Review, 7(1), 83-87. https://doi.org/10.21512/bbr.v7i1.1458

Mujiyana, \& Elissa, I. (2013). Analisis Faktor-Faktor yang Mempengaruhi Keputusan Pembelian Via Internet pada Toko Online. Jurusan Manajemen, Fakultas Ekonomi Universitas Gunadarma, $\operatorname{VIII}(3), 143-152$.

Ngafifi, M. (2014). Kemajuan Teknologi dan Pola Hidup Manusia dalam Perspektif Sosial Budaya. Jurnal Pembangunan Pendidikan: Fondasi dan Aplikasi, 2(1), 33-47. https://doi.org/10.21831/jppfa.v2i1.2616

Poorrezaei, M. (2016). Customer Engagement: Conceptualisation, Measurement and Validation.In PhD Thesis. University of Salford 
Purnami, N. M., \& Kusuma, A. A. G. A. A. (2017). Peran Customer Engagement Memediasi Pengaruh Persepsi Nilai terhadap Loyalitas Konsumen. Seminar Nasional Sains dan Teknologi, 4(Inovasi Humaniora, Sains dan Teknologi untuk Pembangunan Berkelanjutan), 102-108.

Purnomo, S. M., \& Isharina, I. K. (2013). Pengaruh Twitter Account @IniBaruHidup sebagai Social Media terhadap Loyalitas Merek Nescafe Indonesia. Jurnal Ilmiah Mahasiswa FEB, 1(2), 1-9.

Rahmawati, E., \& Sanaji. (2015). Pengaruh Customer Engagement terhadap Kepuasan Pelanggan dan Kepercayaan Merek serta Dampaknya pada Loyalitas Merek. Jurnal Riset Ekonomi an Manajemen, 15(2), 246-261. https://doi.org/10.17970/jrem.15.150204.id

Riyanto, A. D. (2020). Hootsuite (We are Social): Indonesian Digital Report 2020. In Andi.Link (pp. 1-92). (https://datareportal.com/reports/digital-2020-indonesia, diakses pada tanggal 19 Oktober 2020).

Rowley, J. (2015). Building brand webs: Customer relationship management through the Tesco Clubcard loyalty scheme. International Journal of Retail \& Distribution Management, 33(3), 194-206. https://doi.org/https://doi.org/10.1108/09590550510588361

Rudyanto, R. (2018). Pengaruh Pemasaran Jejaring Media Sosial dan Keterkaitan Konsumen Terhadap Niat Beli Konsumen. Jurnal Manajemen dan Pemasaran Jasa, 11(2), 177. https://doi.org/10.25105/jmpj.v11i2.3126

Salem, S. F., \& Salem, S. O. (2019). Effects of Social Media Marketing and Selected Marketing Constructs on Stages of Brand Loyalty. Global Business Review, 1-24. https://doi.org/10.1177/0972150919830863

Schiffman, L. G., \& Kanuk, L. L. (2004). Customer Behaviour (8th ed.). English: Prentice Hall.

So, K. K. F., King, C., Sparks, B. A., \& Wang, Y. (2014). The Role of Customer Engagement in Building Consumer Loyalty to Tourism Brands. Journal of Travel Research, 1-15. https://doi.org/10.1177/0047287514541008

Sukamdewi, R. A., \& Prihatsanti, U. (2018). Hubungan antara Brand Trust dengan Customer Engagement pada Mahasiswi Pengguna Wardah Kosmetik. Jurnal Empati, 6(4), 131-136.

Sunarto. (2009). Manajemen Pemasaran 2. Yogyakarta: Aditya Media.

Taprial, V., \& Kanwar, P. (2012). Understanding Social Media. In Journal of Chemical Information and Modeling (Vol. 53, Issue 9).

Tatar, Sahika, I. E. E. (2016). The effect of social media marketing on brand trust and brand loyalty for hotels. Information Technology and Tourism, 16(3), 249-263. https://doi.org/10.1007/s40558-015-0048-6

Ting, D. H., Abbasi, A. Z., \& Ahmed, S. (2020). Examining the mediating role of social interactivity between customer engagement and brand loyalty. Asia Pacific Journal of Marketing and Logistics. https://doi.org/10.1108/APJML-10-2019-0576

Tuten, T., Solomon, M., \& Ladik, D. (2015). The Teaching of Social Media Marketing. Houston, USA: Springer, Cham. https://doi.org/https://doi.org/10.1007/978-3-319-10912-1_155

Utami, G. R., \& Saputri, M. E. (2020). Pengaruh Social Media Marketing terhadap Customer Engagement dan Loyalitas Merek pada Akun Instagram. Jurnal Riset Manajemen dan Bisnis, 5(2), 185-198. 
Rachmadhaniyati dan Sanaji. Pengaruh Social Media Marketing terhadap Customer Engagement dengan Loyalitas Merek dan Kepercayaan sebagai Variabel Mediasi

Veno, M., \& Subagio, H. (2013). Analisa Pengaruh Kepercayaan terhadap Tenaga Penjual (Trust in Employee), dan Kepercayaan terhadap Merek (Trust in Brand) terhadap Niat Beli (Purchase Intention) Konsumen pada Bernini Furniture di Surabaya, dan Semarang. Jurnal Manajemen Pemasaran Petra, 1(2), 1-12. https://media.neliti.com/media/publications/131917-ID-analisapengaruh-kepercayaan-terhadap-te.pdf

Vivek, S. D. (2009). A Scale of Customer Engagement. Reseacrh Gate. [University of Alabama]. https://www.researchgate.net/publication/228798775_A_scale_of_Customer_Engagement.

Vivek, S. D., Beatty, S. E., Dalela, V., \& Morgan, R. M. (2014). A generalized multidimensional scale for measuring customer engagement. Journal of Marketing Theory and Practice, 22(4), 401-420. https://doi.org/10.2753/MTP1069-6679220404

Vivek, S. D., Beatty, S. E., \& Morgan, R. M. (2012). Customer engagement: Exploring customer relationships beyond purchase. Journal of Marketing Theory and Practice, 20(2), 122-146. https://doi.org/10.2753/MTP1069-6679200201

Wasli, A. (2021). Pengunjung Marketplace Tertinggi Februari 2021 Pada Iprice. Teknologi.Id. (https://iprice.co.id/insights/mapofecommerce, diakses pada tanggal 20 Juni 2021).

Weinberg, T. (2009). The New Community Rules: Marketing on The Social Web (1st ed.). Sebastopol, CA: O'Reilly Media.

Wong, K. K.-K. (2013). Partial Least Squares Structural Equation Modeling (PLS-SEM) Techniques Using SmartPLS. Marketing Bulletin, 24(1), 1-32.

Yunaida, E. (2017). Pengaruh Brand Image (Citra Merek) terhadap Loyalitas Konsumen Produk Oli Pelumas Evalube di Kota Langsa. Jurnal Manajemen dan Keuangan, 6(2), 798-807. https://doi.org/10.33059/jmk.v6i2.685

Zulfikar, A. R. (2017). Pengaruh Social Media Marketing terhadap Brand Trust pada Followers Instagram Dompet Dhuafa Cabang Yogyakarta. Jurnal Manajemen dan Administrasi Islam, 1(2), 279-294. 